\title{
Internal Control Systems Implementation and Fraud Mitigation Nexus among Deposit Taking Saccos in Kenya
}

\author{
David Gathanju Riitho ${ }^{1}$ and Kevin Wanjala ${ }^{2}$ \\ ${ }^{1}$ University of Nairobi, Kenya \\ ${ }^{2}$ Egerton University, Kenya \\ Corresponding Author: wanjalakevin89@gmail.com \\ https://riiopenjournals.com/index.php/finance-economics-review
}

Doi: https://doi.org/10.38157/finance-economics-review.v2i1.59

Citation: Riitho, D. G., \& Wanjala, K. (2020). Internal Control Systems Implementation and Fraud Mitigation Nexus among Deposit Taking Saccos in Kenya. Finance \& Economics Review, 2(1), 11-29. Doi: https://doi.org/10.38157/finance-economicsreview.v2i1.59

\section{Research Article}

\begin{abstract}
Purpose: This paper analyses the relationship between the implementation of internal control and fraud mitigation among the savings and credit cooperatives societies (Saccos) in Kenya.

Methodology: To achieve the objective, specific variables were formulated based on the five components of internal control model. Particularly, the research focuses on the effect of control environment, control activities, monitoring, information and communication, and risk assessment, on fraud mitigation. Data was collected through the use of a structured questionnaire. Ordinary Least Square Regression approach was used for analysis.

Results: The data analysis found that all the mentioned variables significantly affect fraud mitigation among Saccos in Kenya.

Implications: The analysis highlighted that there is a need for Saccos to strive and implement internal control systems to a higher extent to cure the persistent problem of fraud that they grapple with. The analysis also recommends that Saccos should institute proper mechanisms to provide adequate checks during staff recruitment, install adequate security, provide regulation of valuable information access, they should also conduct regular monitoring of third party links with personnel as measures to mitigate fraud.
\end{abstract}

Keywords: Deposit-taking Sacco, internal control system, fraud mitigation, Kenya

\section{Introduction}

Saccos occupy an important position in the global financial system through money supply by affording cheap credit to their vast members. According to a 2016 report by Consultative Group to Assist the Poor, Saccos play a critical role in financial inclusion and poverty alleviation as 
they target customers from specific employment group, business group or locality. Further, the report asserts that, by taking part in the process of financial intermediation, Saccos also provide considerable benefits to borrowers in so far as there may be difficulties in locating potential savers who are willing to lend an appropriate amount of funds at a relevant interest rate.

Hadi and Kamaluddin (2015) posit that it is the simplicity of operations, requirement of the small sum of deposits and issuance of loans with little or no collateral that distinguishes Saccos from commercial banks and other financial institutions. It is their ease in the ability to deposit and lend that sets them apart and leads to their contribution to economic growth and development. According to Besley and Persson (2013), the efficient mobilization of savings and allocation of productive investment by Saccos not only helps them in achieving their objectives of staying solvent and making profit but in a way, it exerts influence on the pattern of economic growth and development.

Like other organizations, Saccos have established systems of controls for the efficient and effective running of their operations to achieve goals. Internal control systems are becoming indispensable owing to evolving complex methods of doing business including the use of technology which exposes businesses to multiple business risks, among them being fraudulent activities. Kamaliah et al., (2018) point out that internal controls are among the mechanisms employed by organizations to help deter, prevent and mitigate fraud incidents.

Several theories discuss internal control systems and fraud, and this study will use Systems Theory, Fraud Triangle Theory and Fraud Management Lifecycle Theory. Systems Theory popularized by Harvey and Brown (1998) states that strong internal control systems help an organization comply with laws and regulations, reduce risks and observe internal policies. Internal control systems can, therefore, aid an organization to detect, prevent and mitigate fraud. The Fraud Triangle Theory developed by Cressey (1953) states that people engage in fraud due to perceived pressure, opportunity and rationalization. An opportunity arises from weak internal controls or lack of proper monitoring of the controls by management. According to Fraud Management Lifecycle Theory developed by Wilhelm (2004), fraud mitigation is one of the mechanisms of dealing with fraud and cites some of the mitigation measures as internal auditing, which works hand in hand with the internal control system.

\subsection{Deposit Taking Saccos in Kenya}

Saccos are documented to have contributed tremendously to the gross domestic product in Kenya. In 2017 alone, the mobilized savings in Sacco was 30 per cent of gross domestic saving (SASRA, 2017). However, despite much achievement, they have not been spared from cases of corruption and fraud. Major cases of fraud reported include manipulation of financial statement, misappropriation of funds, and mismanagement of members' asset, which threaten the survival of many Saccos in Kenya (Wanjama, 2019). Multiple cases of fraud in Saccos prompted the government to institute measures to curb issues of fraud, notably among them the establishment of the Sacco Societies Regulatory Authority (SASRA) in 2009, under Sacco Societies Act of 2008, to supervise and regulate the conduct of Saccos in Kenya. 
However, despite such measures, cases of fraud are still rampant. Recently many Saccos have been reported to be involved in corrupt dealings. For instance, the board of Stima Deposit Taking Sacco was disbanded on February 19 2019 following allegations of misappropriation of KShs 500 million in suspect land transactions (Fayo, 2019). Similarly, Ekeza Sacco was reported to have lost KShs 1.5 billion in irregular cash transfers (Koech, 2019). In 2018, Safaricom Sacco staff were among nine suspects arrested in connection to the hacking of Sacco's information technology systems and theft of millions of shillings (Fayo, 2018). In 2018, a senior manager in Harambee Sacco was charged with theft of KShs 13.6 Million (Walter, 2018). Analysts have linked the massive loss of members' money to poor management and weak governance (Fayo, 2019). Nothing is however mentioned about the internal control systems and whether their absence or inadequacy could have resulted in enormous fraud. This is despite a 2012 report by PROCASUR Africa stating that internal control is poor among Saccos and a capable culprit in the fraud cases. For this reason, this study intends to focus on deposit-taking Saccos in Kenya, to determine how internal control systems affect mitigation of fraud.

\subsection{Problem Statement}

The role of internal control systems is gaining a lot of importance because of the changing technological environment, increase in business risks and complexities of handling business transactions. Systems theory advocates for the presence of an internal control mechanism as a way of enhancing the general operations of an entity in line with setting out goals, mission and objectives (Harvey \& Brown, 1998). On the other hand, fraud triangle and fraud management lifecycle theories argue that an organization's efficiency and effectiveness in reducing or mitigating fraud incidents and impact is contingent upon internal control systems set up and implemented by the organization. Therefore this shows that firms should place more focus on enhancing their internal controls to boost their efforts in mitigating potential risks, including fraud.

An increasing number of Saccos in Kenya are facing difficulties emanating from cases of fraud that are slowly threatening their survival. The Sacco sector which accounts for 45 per cent of Kenya's GDP and 30 per cent of domestic savings is on the verge of becoming unstable, and if this goes unchecked, chances are it might have detrimental effects to the economy at large (Fayo, 2019). At stake is the billions of Kenyan shillings that members have contributed in terms of mobilized deposit and saving that are either lost or on the brink of being lost due to fraudulent activities. There is no doubt that measures need to be put in place to save the sector. The Saccos have to work on their internal control systems to safeguard resources in a feat to curb the incidences of fraud. The recent challenges facing the sector raise questions on the adequacy of their internal controls and fraud mitigation measures and hence the need for further study.

Both international and local studies have been conducted where conflicting results have been found. Abbott et al (2000) found that loopholes in internal controls act as catalysts in the commission of fraud. Zakaria et al (2016) identified internal control weaknesses as a major contributing factor for fraud to be committed. Okonkwo et al (2016) cited lack of effective internal control systems/ techniques to be a major cause of fraud in banks. Le and Tran (2018) 
found that all COSO components of internal control contribute significantly towards fraud control. PROCASUR Africa (2012) has cited poor internal control systems to be the primary facilitator of fraud among financial institutions and by extension Saccos. The 2018 Sacco Cyber Security Report by Serianu indicates that inadequate internal controls in technology-related matters have left Saccos exposed to cybercrimes. Branch and Baker (1998) identify weak internal controls as a major weakness of Saccos, which lead directors to manipulate procedures on credit granting to their favour. KPMG Fraud Survey Report (2009) points out that very poor internal controls play a major role in increasing fraud levels in organizations. Ali (2013) states that ineffective and imperfect internal control practices are the main causes of financial problems experienced in most financial institutions. Idogei et al., (2017) identified a positive relationship between the quality of controls and reduction in fraud incidences. However, Rae and Subramaniam (2008) posit that they have observed that there are organizations with vibrant internal control systems but still, they are marred by fraud cases while there are ones with no internal system at all but there are no cases of fraud.

Locally, Makau (2017) identified a positive relationship between the quality of controls and identification and reduction of fraud risks. Kiprop (2010) found out fraud detection systems have a positive influence on reducing fraud-related challenges. Wanyama (2012) established internal control to be an effective strategy in responding to fraud. Oguda, Odhiambo and Byaruhanga (2015) found a statistically significant positive influence between adequacy of internal controls and prevention and detection of fraud while studying the effect of fraud prevention and detection in district treasuries of Kakamega County.

Although the findings of all studies undertaken in Kenya so far indicate positive responses to fraud mitigation, there still lies a gap since none of the studies have dealt on the direct impact of internal controls on fraud mitigation among deposit taking Saccos in Kenya. The extant literature is saturated with knowledge on internal control and fraud, and impact on performance, mainly in the banking industry. Besides, most of the studies conducted globally show mixed reactions concerning internal controls and fraud mitigation. The lack of consensus among various arguments on the relationship between internal controls and fraud mitigation is reason enough to conduct a further examination on the area. It is against this backdrop that this study will be conducted to determine how internal control system influences fraud mitigation on deposit-taking Saccos in Kenya.

\section{Literature Review}

This section presents the theoretical literature that is closely related to the study. It also conceptualizes the variables and their possible effects on fraud mitigation.

\subsection{Systems Theory}

The theory postulates that a system of internal control is important for organizational management. It is a platform for safe and sound operations. A strong system can help ensure goals and objectives are met to achieve long-term targets. Through it, the organization can comply with laws and regulations, internal policies, reduce risks of unexpected losses, and prevent reputational damage. An internal control system is a concept that was first brought to 
light in 1992 by the Committee of Sponsoring Organizations of the Treadway Commission (COSO). The commission developed an integrated framework that laid down all the systems which when followed to the letter would lead to detection, prevention and mitigation of fraud. Systems theory was popularized by Harvey and Brown (1998) based on the 1992 COSO framework and pointed out that internal control system has effectively worked in fraud mitigation and should, therefore, be embraced and adopted by every organization a key policy in fraud mitigation. They, however, assert that the five elements are not sufficient by themselves and that other elements need to be added alongside the five. They suggested accounting classification and controlled classification as other key elements missing in the model. Grieves (2000) was also in support of the internal control systems model but was of the view that administration oversight and adjusting insufficiencies should be included in the internal control systems. Rae and Subramaniam (2008) however dispute the effectiveness of the model as they have observed that there are organizations with vibrant internal control systems but still are marred by fraud cases, while there are others with no internal system at all but without cases of fraud. Amudo and Inanga (2009) state that for a system to be effective, all elements of internal control as outlined by COSO (control environment, risk assessment, information and communication, monitoring and control activities) must be present and interact seamlessly.

\subsection{Internal Control Elements}

Internal control elements put across by systems theory are explained in details in the following sections

\subsubsection{Control Environment}

Ayagre et al (2015) found that a strong control environment and monitoring components of internal control invariably assist in fraud deterrence. Hayes (2005) indicates that control environment sets the internal control tone of the organization in terms of providing a conducive atmosphere for the coexistence of the employees and administration. Conducive work climate is an important deterrent of employee fraud (Kulas et al, 2007), while top management's support for internal controls is said to reduce cases of fraud in general significantly (Holmes et al, 2002). Control environment includes aspects such as proper staff recruitment process, better allocation and delegation of duties, fair remuneration and compensation as well as the existence of well laid out ground rules in the organization (COSO, 1992).

\subsubsection{Risk Assessment}

COSO (1992) points out that, there is a need to carry out a risk assessment in an organization failure to which an organization might be caught by surprise. Fraud has been highlighted as one of the main risks that organizations are susceptible to. IIA (1999) posit that fraud risk assessment is important for determining the probability of its occurrence, its likely magnitude as well as ways of mitigation. Ward and Smith (2002) state that the process of identifying and analyzing risks is continuously ongoing and vital for the internal control system and appropriate actions should be taken once risks are detected. 


\subsubsection{Control Activities}

These are actions put in place to ensure that the directives of the management are followed. This element also stipulates the necessary activities needed to prevent fraud and other risks the organization might face. Amudo and Inanga (2009) viewed that authorization, segregation of duties, verification before making payments, control over access to resources, reconciliation review of operations, and supervision are the control activities of an organization. Barra (2010) showed that the presence of control activities increases the cost of committing fraud and thus acts as deterrence.

\subsubsection{Information and Communication}

Information and communication are considered important for passing across what requires to be implemented and their procedures (Hayes, 2005). Information and communication element requires that proper systems be in place for passing information, communication be passed in good time, information is complete and accurate, employees have all the information about the organization, more so about their roles (COSO, 1992). Communication with various stakeholders is best when such is documented for continuous review and action. An open and effective communication culture in organization aids in detecting the possibility of fraud in advance (Hayali et al, 2013), and thus put necessary measures to prevent and mitigating fraud cases.

\subsubsection{Monitoring}

Monitoring involves evaluation of the entire internal control system over time for management to be confident regarding its effectiveness (Tunji, 2013) and entails checks and inspections, external audits, internal audits, peer evaluations, as well as internal evaluations. For monitoring to fully achieve its objective of fraud mitigation, it must be supported by the top brass in the organization, it must be assigned to competent individuals within the organization and finally, it must follow a baseline survey. All employees should understand the mission, objectives and risk tolerance levels of their organization, and their responsibilities, for monitoring to be effective. Romar and Moberg (2003) found out that lack of stringent monitoring systems was among factors that contributed to the WorldCom scandal of 2002 hence controls around posting journal entries were not identified as weak. By continuously monitoring, fraudulent actions can be revealed and dealt with within the shortest time possible (Hayali et al, 2013). Besides, internal controls must be continuously reviewed to determine their effectiveness (Amudo and Inanga, 2009).

\subsubsection{Empirical Studies}

This section reviews the current state of the subject and provides evidence on prior studies. The purpose of the section is to uncover existing gaps in the literature and how the study contributes to resolving such gaps. Various critiques are drawn in the section. The section further lays the basis for comparison of the results of the current study to existing literature. Abbott et al., (2000) studied internal auditing as a measure of curbing fraud in 156 firms, 78 of them subject to SEC Accounting and Enforcement Releases, and 78 similar firms but not 
sanctioned by SEC. They found that internal control was very effective in reducing fraudulent activities in companies that were highly susceptible to fraud. The study creates a contextual knowledge gap as it was done on public and private companies in the USA.

Zhang et al., (2007) did a study to determine the relationship between audit committee quality, auditor independence and weak internal control systems, after the enactment of the SarbanesOxley Act. A sample of 208 firms in the United States with material internal control weaknesses was studied using matched-pairs design. The study established that these firms also reported high cases of fraud. Similarly, Elder et.al (2008) studied auditors' client risk management after a year following the enacting of the Sarbanes Oxley Act. Using a sample of 2350 organizations, the study established that internal auditing is an integral part of fraud mitigation and those internal control systems are effective in the management and mitigation of fraud.

Zakaria et al (2016) examined types of internal control weaknesses and their impact on fraud in oil and gas companies. They used a case study approach and collected data using document analysis and interviews. Data analysis was conducted using qualitative software. The study found that there was a need to strengthen internal controls to reduce opportunities for fraud committed in a company. The study creates a contextual gap in that it was conducted on an oil and gas organization in Malaysia.

Okonkwo et al (2016) examined the extent the internal control techniques have checked the practice of bank fraud. They used the survey method and targeted mainly bank staff and customers with structured questionnaires. A sample size of 226 was used, and descriptive statistics expected frequency response and Likert scale ranking were used to analyze the data. Each hypothesis was tested using the Chi-Square statistic at 5\% level of significance. The study found that internal control techniques had not been effective in preventing bank fraud and there was a need for banks to create strong internal control systems to stand against the wiles of fraud. The study creates contextual gap as it was conducted on banks in Nigeria.

Le and Tran (2018) examined the impact of COSO five internal control components on asset misappropriation in Vietnamese firms. Using questionnaires, the researchers collected 279 responses from internal auditors, accountants and departmental heads. The relationship was tested using Pearson's correlation and multiple regression analysis, and results showed that while all components had a significant influence on reduction in asset misappropriation, there was a need to strengthen them so as to reduce fraud incidences.

Makau (2017) researched on cash management practices of Saccos in Nairobi County. Descriptive research design was used. A sample of 39 Saccos was selected using stratified sampling, and data collected using structures questionnaires. Data was analyzed using regression and correlation analysis. The study found that there was a need to strengthen internal controls in cash management so as to be able to identify and minimize risks of fraud and misappropriation of funds. The study was limited to cases of fraud in cash management systems.

Kiprop (2010) conducted a case study on responses by the management to fraud-related challenges by Barclays Bank of Kenya. Using semi-structured questionnaires, and content 
analysis, the study established that there were proper systems in place. However, the study did not evaluate the levels of controls in managing fraud.

Munyua (2013) conducted a case study of how banks respond to credit card fraud by commercial banks in Kenya. The study used descriptive and correlation analysis and established that mixed operational approach has been instituted to deal with credit card fraud. This study, however, targets banks and only focused on credit card fraud. Wanyama (2012) carried out a study on the effectiveness of fraud response strategies by the Cooperative Bank of Kenya. The study used the open-ended questionnaire to collect data. The study established that fraud cannot be mitigated using an inadequate control system.

Kamau (2016) investigated the causes and characteristics of fraud in Kenya Saccos. The study used chi-square approach to carry out analysis on secondary data from Saccos. It was established that data manipulation and human bias are major causes for fraud among Kenyan Saccos. The study did not, however, look at how it can be mitigated. Additionally, it only focused on fraud in accounting statements.

Kimani (2011) conducted a fraud risk assessment plan for Barclays Bank of Kenya. According to the researcher, the majority of frauds are detected through tips reported by either employees, vendors or whistle-blowers. The study concluded that in order for BBK to be able to prevent and reduce fraud to a minimum, fraud risk assessment team of the bank should follow a fraud risk assessment strategy which provides guidelines that help prevent, detect, manage and resolve the fraud.

\section{Methodology}

This section research design, the study population, sample of the study, data collection procedures as well as data analysis

\subsection{Research Design}

Cooper and Schindler (2001) define research design as a strategic plan for investigating the relationship between the variables for purposes of answering the research questions. This study used descriptive research design. Kothari (2003) states that descriptive research design is an approach to research that attempts to describe the causality of the independent variables on the dependent variable. Descriptive research design was preferred because the study sought to establish the impact of internal control systems as an independent variable, on fraud mitigation, the dependent variable, among deposit taking Saccos in Kenya.

\subsection{Study Sample}

A sample is a smaller group or sub-group obtained from the population (Mugenda and Mugenda, 1999). In the study, four managers were purposively selected for interviews based on their knowledge of internal control systems and fraud mitigation. They are account, credit, procurement managers, and internal auditor. Purposive method was used to select a sample of all the 44 deposit taking Saccos that mainly operate in Nairobi City County as per SASRA licensing report, 2018. Purposive sampling is a deliberate selection of segments of the 
population to have a representative sample of the population (Kothari, 2004). Therefore the targeted respondents were 176.

\subsection{Data collection}

Data was collected through the use of a structured questionnaire. The questionnaires were administered to targeted respondents through "drop and pick" method. The questionnaire had seven sections. The first section entailed the respondent's demographic background. Section two collected information on control environment, section three on risk assessment, section four on control activities, section five on information and communication systems, section six on monitoring activities, and section seven on fraud mitigation. A five-point Likert scale was used for the closed-ended questions where 1-not at all, 2-low extent, 3-moderate extent, 4-high extent and 5-very high extent. The targeted respondents were account, procurement, credit, and audit managers.

\subsection{Analytical Model}

The Ordinary Least Square is the analytical model is used in analysing the interrelationship of predictor variables on the response variable. The model of the study was in the form:

$$
Y=\beta_{0}+\beta_{1} X_{1}+\beta_{2} X_{2}+\beta_{3} X_{3}+\beta_{4} X_{4}+\beta_{5} X_{5}+\varepsilon
$$

Where;

$\mathrm{Y}=$ Fraud mitigation - measured using five-point Likert Scale

$X_{1}=$ Control Environment - measured using five-point Likert Scale

$X_{2}=$ Risk Assessment - measured using five-point Likert Scale

$X_{3}=$ Control Activities - measured using five-point Likert Scale

$X_{4}=$ Information and Communication - measured using five-point Likert Scale

$X_{5}=$ Monitoring - measured using five-point Likert Scale

$\beta_{0}=$ Constant or $\mathrm{Y}$-intercept, that is, the value of $\mathrm{Y}$ when $\mathrm{X}$ is equal to zero

$\beta_{1}, \beta_{2}, \beta_{3}, \beta_{4}$ and $\beta_{5}$ are partial slope coefficients of the model

$\varepsilon=$ The error term of the model

\section{Results}

This section presents the analysis of results obtained from descriptive statistics and regression analysis.

\subsection{Descriptive Statistics}

This study aimed to determine the effect of internal control system on fraud mitigation among the deposit-taking Saccos in Kenya. To achieve this objective, six sets of questions were constructed, 5 were related to the components of the internal control system while one was related to fraud mitigation. These questions were measured using a five-point Likert scale to obtain results. Scaling ranged from 1-5 where 1 indicated that the respondent strongly disagrees 
and 5 indicated that they strongly agree with the statements/item. Mean and the standard deviation was used to present these results.

\subsubsection{Control Environment}

Control Environment was measured by a score of six items on a 5-point Likert scale that is informed by the characteristic of the control environment. It was, therefore, important to ask the respondents about the control environment to get a clear picture of the level of its implementation in the organization. The average mean for the 9 items was 3.92, this shows that the respondents agree that the control environment was being implemented to a moderate extent among deposit taking Saccos. The average standard deviation was 0.528 an indication that the respondents' views on the subject were not varied. Results are displayed in Table 1.

Table 1: Descriptive Statistics for Control Environment

\begin{tabular}{|lll|}
\hline Statement & Mean & $\begin{array}{l}\text { Std. } \\
\text { deviation }\end{array}$ \\
\hline $\begin{array}{l}\text { Background, competency and integrity checks are } \\
\text { performed during staff recruitment }\end{array}$ & .96 & .788 \\
\hline $\begin{array}{l}\text { A clear chain of command is reflected in organizational } \\
\text { structure }\end{array}$ & 4.32 & .469 \\
\hline Regular follow-ups are done on delegated responsibilities & 4.18 & .529 \\
\hline Employee promotion and compensation is done fairly & 4.21 & .483 \\
\hline Staff training is undertaken regularly & 4.07 & .410 \\
\hline Employees proceed on annual leave each year & 4.10 & .595 \\
\hline $\begin{array}{l}\text { To what extent do employees and management comply } \\
\text { with existing Sacco regulations, rules and procedures? }\end{array}$ & 4.20 & .540 \\
\hline $\begin{array}{l}\text { Existing policies can deal with conflict of interest, code of } \\
\text { conduct and insider borrowing }\end{array}$ & 4.18 & .389 \\
\hline $\begin{array}{l}\text { Credit management policies and limits are strictly } \\
\text { followed }\end{array}$ & 4.12 & .551 \\
\hline Average Mean and Std. Deviation & 3.92 & .528 \\
\hline
\end{tabular}

\subsubsection{Risk Assessment}

The study aimed to determine the effect of risk assessment on fraud mitigation among the deposit-taking Saccos in Kenya. To achieve this, the five-point Likert scale was used to rate the responses elicited by the study respondents. The average mean was 4.391 meaning that the respondents agree to a high extent that Saccos implement risk assessment. The standard deviation was 0.5407 an indication that the respondents were speaking in one voice. Results are displayed in Table 2. 
Table 2: Descriptive Statistics for Risk Assessment

\begin{tabular}{|c|c|}
\hline Statement & $\begin{array}{l}\text { Std. } \\
\text { Deviation }\end{array}$ \\
\hline $\begin{array}{l}\text { Mechanisms in place to mitigate risks as they occur are } 4.68 \\
\text { effective }\end{array}$ & .469 \\
\hline Processes of identifying and estimating risks are effective & .501 \\
\hline $\begin{array}{l}\text { Security checks in and out of Sacco premises have enabled } 4.24 \\
\text { Sacco assets to be secure }\end{array}$ & .700 \\
\hline Examination of personnel before changes in duties is valuable 4.39 & .577 \\
\hline $\begin{array}{l}\text { Vetting potential Sacco members before admission have4.32 } \\
\text { reduced various risks that may affect Sacco }\end{array}$ & .469 \\
\hline $\begin{array}{l}\text { Thorough checks before loans are disbursed to members and } 4.18 \\
\text { in dealing with other stakeholders have proved very helpful in } \\
\text { avoiding defaults and other risks }\end{array}$ & .529 \\
\hline Average Mean and Standard Deviation & 0.5407 \\
\hline
\end{tabular}

\subsubsection{Control Activities}

To examine the effect of control activities on fraud mitigation among the Saccos in Kenya, a questionnaire with 9 items related to control activities was constructed. The overall mean for the 9 items was 3.9 an indication that control activities are implemented to a moderate extent among the Saccos in Kenya. The overall standard deviation was 0.502 meaning that the respondents were speaking in unison voice. Results are displayed in Table 3.

Table 3: Descriptive Statistics for Control Activities

\begin{tabular}{|c|c|c|}
\hline Statement & Mean & $\begin{array}{l}\text { Std. } \\
\text { Deviation }\end{array}$ \\
\hline \multicolumn{2}{|c|}{$\begin{array}{l}\text { Authorized personnel undertake various transactions assigned without re- } \\
\text { delegating }\end{array}$} & .483 \\
\hline Reconciliations on books of accounts are done regularly & 4.07 & .410 \\
\hline Frequent job rotation has strengthened internal controls & 4.10 & .595 \\
\hline Verifications are done to reduce the chances of forgery & 4.20 & .540 \\
\hline Clearly defined duties are assigned to each staff & 4.18 & .389 \\
\hline \multicolumn{2}{|l|}{$\begin{array}{l}\text { It is difficult for an employee to access all valuable information without } \\
\text { authorization by senior staff }\end{array}$} & .788 \\
\hline \multicolumn{2}{|l|}{$\begin{array}{l}\text { Various levels of approvals before transactions are authorized by senior } \\
\text { staff are adhered to }\end{array}$} & .469 \\
\hline \multicolumn{2}{|c|}{ Strict and controlled access to sensitive assets e.g. cash, cheques, is observed 4.18} & .529 \\
\hline Segregation of duties has enabled more efficient operations of the Sacco & 4.21 & .483 \\
\hline Average mean and Standard deviation & 3.96 & 0.502 \\
\hline
\end{tabular}




\subsubsection{Information and Communication System}

To examine the effect of information and communication systems on fraud mitigation among the Saccos in Kenya, 7 items related to information and communication system was constructed. The average mean for the 7 items of information and communication systems was 4.86 . This shows that the respondents agree to a very high extent that Saccos have implemented information and communication systems as a strategy of fraud mitigation. The standard deviation for the items was 0.569 meaning that they did not have differing views. Results are displayed in Table 4.

Table 4: Descriptive Statistics for Information and Communication System

\begin{tabular}{|c|c|c|}
\hline Statement & Mean & $\begin{array}{l}\text { Std. } \\
\text { Deviation }\end{array}$ \\
\hline Regular follow-ups are done on delegated responsibilities & 4.18 & .529 \\
\hline The established systems of passing information are effective & 4.07 & .410 \\
\hline There are no conflicts between staff regarding assigned roles & 4.10 & .595 \\
\hline \multicolumn{2}{|c|}{$\begin{array}{l}\text { There are no anomalies between information supplied by external } \\
\text { parties and Sacco financial statements on various transactions } 4.20 \\
\text { verified }\end{array}$} & .540 \\
\hline \multicolumn{2}{|c|}{$\begin{array}{l}\text { Reports received by management are usually timely, relevant and } \\
\text { reliable for decision making }\end{array}$} & .389 \\
\hline Management acts upon various findings quickly & 4.12 & .551 \\
\hline \multicolumn{2}{|c|}{$\begin{array}{l}\text { All transactions are recorded in a complete, timely and accurate } \\
\text { manner }\end{array}$} & .469 \\
\hline \multicolumn{2}{|c|}{ Every employee is well aware of the Sacco's internal control systems 4.53} & .501 \\
\hline Average mean and Standard deviation & 4.86 & 0.569 \\
\hline
\end{tabular}

\subsubsection{Monitoring Activities}

The study aimed to examine the effect of monitoring activities on fraud mitigation among the Saccos in Kenya. To achieve this, a questionnaire with 7 items was constructed. The overall mean for the 7 items of monitoring activities was 4.216 meaning that the respondents agree to a high extent that there are monitoring activities in place with the deposit-taking Saccos. The overall standard deviation was 0.537 an indication that they did not have divergent opinions. Results are displayed in Table 5. 
Table 5: Descriptive Statistics for Monitoring Activities

\begin{tabular}{|c|c|c|}
\hline Statement & Mean & $\begin{array}{l}\text { Std. } \\
\text { Deviation }\end{array}$ \\
\hline Staff evaluation mechanisms reflect properly employee's productivity & 4.24 & .700 \\
\hline All plans for Sacco activities are keenly followed & 4.39 & .577 \\
\hline $\begin{array}{l}\text { Lack of clear observance of laid down rules and regulations attrac } \\
\text { disciplinary measures from management }\end{array}$ & ts 4.32 & .469 \\
\hline $\begin{array}{l}\text { Continuous checks on internal controls are followed by prompt actions } k \\
\text { management to strengthen controls where there are weaknesses }\end{array}$ & $\mathrm{y}_{4.18}$ & .529 \\
\hline Many staff can meet their performance targets & 4.21 & .483 \\
\hline $\begin{array}{l}\text { There is usually no major variance between the budget and other targe } \\
\text { as compared to actual performance }\end{array}$ & $\mathrm{ts}_{4.07}$ & .410 \\
\hline $\begin{array}{l}\text { Physical inventory counts reflect accurately what is recorded in books } \\
\text { accounts }\end{array}$ & $f_{4.10}$ & .595 \\
\hline Overall mean and Standard deviation & 4.216 & 0.537 \\
\hline
\end{tabular}

\subsubsection{Fraud Mitigation}

Fraud mitigation was measured by a score of 7 items on a 5-point Likert scale. The overall mean for the 9 items was 3.686 meaning that the respondents agree to a moderate extent that there are proper mechanisms in place for fraud mitigation. On the other hand, the overall standard deviation was 0.713 , an indication that the respondents were speaking in one voice. The results for the mean and standard deviation are shown in Table 6

Table 6: Descriptive Results for Fraud Mitigation

\begin{tabular}{|c|c|}
\hline Statement & $\begin{array}{l}\text { Std. } \\
\text { Deviation }\end{array}$ \\
\hline $\begin{array}{l}\text { Established systems and controls can detect, identify and deal with fraud } \\
\text { in the Sacco }\end{array}$ & .788 \\
\hline $\begin{array}{l}\text { Fraud prevention mechanisms incorporated when designing customer } \\
\text { products are effective in fraud mitigation }\end{array}$ & .469 \\
\hline $\begin{array}{l}\text { Established procedures of reporting cases of fraud ensure safety and } \\
\text { privacy of employees and other stakeholders involved in reporting }\end{array}$ & .529 \\
\hline $\begin{array}{l}\begin{array}{l}\text { Employees and stakeholders trust assurance by management in } \\
\text { encouraging whistleblowing }\end{array} \\
\text { enc.21 }\end{array}$ & .483 \\
\hline $\begin{array}{l}\text { Management encourages and performs surprise audits on areas most } \\
\text { vulnerable to fraud }\end{array}$ & .410 \\
\hline $\begin{array}{l}\text { Published policy by Sacco against fraud reflects the seriousness of } \\
\text { management in dealing with fraud }\end{array}$ & .595 \\
\hline Staff training on how to notice signs of fraud yields results & .540 \\
\hline $\begin{array}{l}\text { Disciplinary mechanisms in place to deal with personnel engaging in } 4.18 \\
\text { fraud have led to reduced fraud cases }\end{array}$ & .389 \\
\hline There is regular monitoring of third-party relationships with the Sacco & .788 \\
\hline Average mean and Standard deviation & 0.713 \\
\hline
\end{tabular}

23 Published by Research \& Innovation Initiative, 3112 Jarvis Ave, Warren, MI 48091, USA 


\subsection{Regression Results}

Regression analysis using the Ordinary Least Square was conducted to determine the magnitude and direction of the effect of independent variables that is, control environment, risk assessment, control activities, information and communication systems, and monitoring activities on Fraud mitigation. The results are shown by Tables 7,8 and 9.

Table 7 shows the model summary in terms of the coefficient of determination (R squared), which is important in explaining the goodness of fit of the model. Findings show that the $R$ square is 0.946 , meaning that 94.6 per cent of the disparity in fraud mitigation is explained in the model while the rest (5.4 per cent) is explained by other factors that are excluded from the model. According to Woodridge (2003), a model with a coefficient of determination of above 70 per cent is deemed to be a good fit. The model has satisfied this condition and it is therefore good for predicting the performances from the indicators.

Table 7: Model Summary

\begin{tabular}{|c|c|c|c|c|}
\hline Model & $\mathrm{R}$ & R Square & Adjusted R Square & Std. Error of the Estimate \\
\hline 1 & $.973^{\mathrm{a}}$ & .946 & .945 & .07273 \\
\hline a. & $\begin{array}{l}\text { Predictors: } \\
\text { Control_act }\end{array}$ & $\begin{array}{l}\text { (Constant), } \\
\text { ities, Control }\end{array}$ & $\begin{array}{l}\text { Monitoring_activities, } \\
\text { nvironment }\end{array}$ & Risk_Assesment, \\
\hline
\end{tabular}

Table 8 illustrates the analysis of variance results. The F statistic is 516.046 with a P-value of 0.000. The data is therefore well suited for making a sound deduction on the population's parameter

Table 8: Analysis of Variance

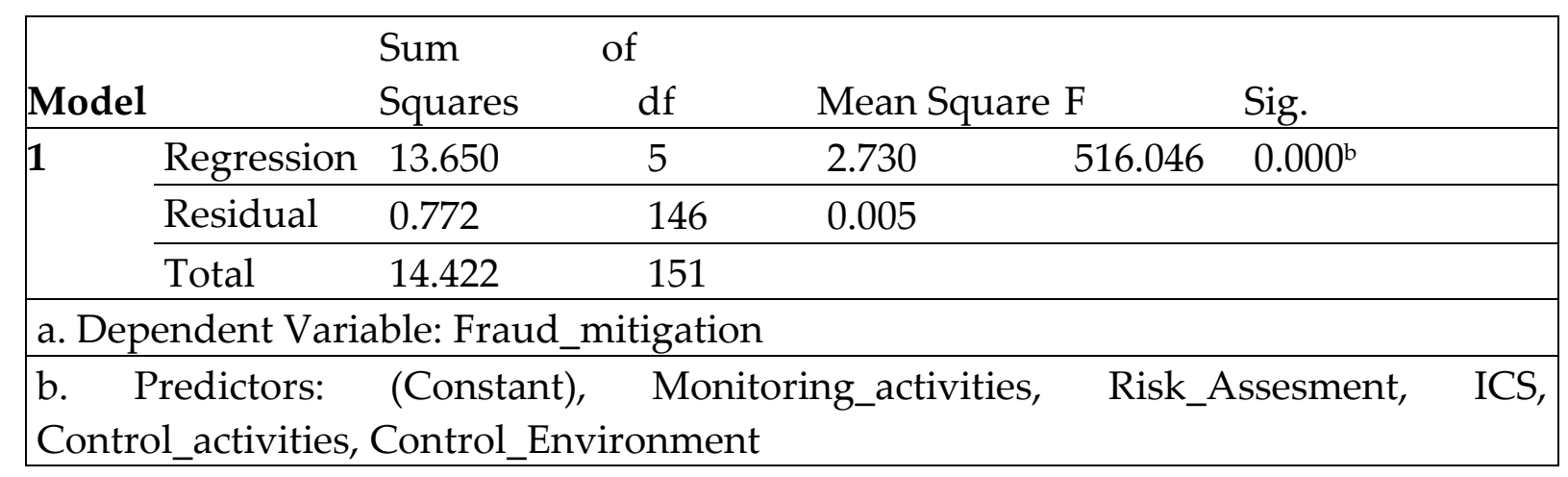

Table 9 shows the regression results. The estimated equation derived from the table will be of the form:

$$
F M=0.237+0.892 C E+0.226 R A+0.525 C A+0.166 I C S+0.572 M A
$$

The Y-intercept is 0.237 meaning that the constant value for fraud mitigation is 0.237 irrespective of the components of internal control. The partial slope coefficient for the control environment is 0.829 and is statistically significant at 5 per cent as indicated by the P-value of 
0.000. These results indicate that a percentage increase in the control environment would lead to a 0.829 per cent increase in the rate of fraud mitigation and vice versa. These results are consistent with the works of Ayagre et al (2015) who found that a strong control environment component of internal control invariably assists in fraud deterrence. The justification for these results is that the control environment sets the internal control tone of the organization in terms of providing a conducive atmosphere for the coexistence of the employees and administration. Conducive work climate is an important deterrent of employee fraud.

The partial slope coefficient for risk assessment is 0.226 and is statistically significant as shown by the P-value of 0.000 . The results show that a 1 per cent increase in the level of risk assessment will have a 0.226 per cent increase in the level of fraud mitigation and vice-versa. These results are in line with the works of Ward and Smith (2002) who established a positive relationship between risk assessment and fraud mitigation. Risk assessment is vital in the early detection of cases of fraud, therefore, it mitigates it before it even happens. It is crucial for determining the probability of its occurrence, its likely magnitude as well as ways of mitigation.

The partial slope coefficient for control activities is 0.525 and is statistically significant as shown by the P-value of 0.000 . The results show that a 1 per cent increase in the level of control activities will have a 0.226 per cent increase in the level of fraud mitigation and vice-versa. These results are consistent with, the works of Amudo and Inanga (2009) and Barra (2010), who found that control activity element has a positive effect on fraud mitigation. The justification for this is that control activity stipulates the necessary activities needed to prevent fraud and other risks the organization might face. The presence of control activities also increases the cost of committing fraud and thus acts as deterrence.

The partial slope coefficient for information and communication systems is 0.166 and is statistically significant as shown by the P-value of 0.000 . The results show that a 1 per cent increase in the level of information and communication systems will have a 0.226 per cent increase in the level of fraud mitigation and vice-versa. This means that a unit increase in information and communication systems level would lead to a 0.166 increase in the level of fraud mitigation. These findings are consistent with the works of Hayes (2005) and Hayali (2013) who found out that information and communication systems have a positive effect on fraud mitigation. The justification for this is that information and communication systems point out the procedures to be followed in fraud mitigation. Hayali et al., (2013) points out that an open and effective communication culture in organization aids in detecting the possibility of fraud in advance and thus puts necessary measures to prevent and mitigating fraud cases.

The partial slope coefficient for monitoring activities is 0.527and is statistically significant as shown by the P-value of 0.000 . The results show that a 1 per cent increase in the level of monitoring activities will have a 0.226 per cent increase in the level of fraud mitigation and viceversa. These results are consistent with the works of Tunji (2003) who established that monitoring activities have a positive effect on fraud mitigation. Monitoring provides continuous monitoring of internal control and therefore it makes it easy to detect any risks as they arise and mitigate them. 
Table 9: Regression Analysis Results

\begin{tabular}{|c|c|c|c|c|c|c|}
\hline \multirow[b]{2}{*}{ Model } & & \multicolumn{2}{|c|}{$\begin{array}{l}\text { Unstandardized } \\
\text { Coefficients }\end{array}$} & \multicolumn{2}{|c|}{$\begin{array}{l}\text { Standardized } \\
\text { Coefficients }\end{array}$} & \multirow[b]{2}{*}{ Sig. } \\
\hline & & $\mathrm{B}$ & Std. Error & Beta & $\mathbf{t}$ & \\
\hline \multirow[t]{6}{*}{1} & (Constant) & 0.237 & .135 & & 1.750 & .082 \\
\hline & Control Environment & 0.892 & .133 & .864 & 6.725 & .000 \\
\hline & Risk Assessment & 0.226 & .035 & .211 & 6.453 & .000 \\
\hline & Control Activities & 0.525 & .128 & .501 & 4.112 & .000 \\
\hline & $\begin{array}{l}\text { Information and } \\
\text { communication system }\end{array}$ & 0.166 & .048 & .152 & 3.482 & .001 \\
\hline & Monitoring activities & 0.572 & .089 & .369 & 6.425 & .000 \\
\hline
\end{tabular}

\subsection{One-Way ANOVA Results}

The study sought to determine whether the levels of internal control implementation play any role in fraud mitigation. To achieve this objective, the One-Way ANOVA method was applied. From the results in Table 4, it can be shown that there is a significant difference in mean among the levels of internal control and their effect on fraud mitigation. This is shown by the $\mathrm{F}$ statistics of 4.181 and the P-value of 0.017 , showing significance at 5 per cent level.

Table 10: One-Way ANOVA Results

\begin{tabular}{|llllll|}
\hline & $\begin{array}{l}\text { Sum } \\
\text { Squares }\end{array}$ & of & $\begin{array}{l}\text { Mean } \\
\text { Square }\end{array}$ & F & Sig. \\
\hline $\begin{array}{l}\text { Between } \\
\text { Groups }\end{array}$ & .766 & 2 & .383 & 4.181 & .017 \\
\hline $\begin{array}{l}\text { Within } \\
\text { Groups }\end{array}$ & 13.656 & 149 & .092 & & \\
\hline Total & 14.422 & 151 & & & \\
\hline
\end{tabular}

\section{Conclusions}

Five conclusions can be drawn from the findings and discussion of results based on the elements of internal control. Firstly, the study concludes that the control environment has a positive effect on fraud mitigation. The control environment sets the internal control tone of the organization in terms of providing a conducive atmosphere for the coexistence of the employees and administration. Conducive work climate is an important deterrent of employee fraud.

Secondly, there is a positive relationship between risk assessment and fraud mitigation. Risk assessment is vital in the early detection of cases of fraud, therefore, it mitigates it before it even happens. It is crucial for determining the probability of its occurrence, its likely magnitude as well as ways of mitigation.

Thirdly, control activities and Saccos have a positive and significant relationship. Control activities provide the necessary activities needed to prevent fraud and other risks the 
organization might face. The presence of control activities also increases the cost of committing fraud and thus acts as deterrence.

Fourthly, information and communication and fraud mitigation have a positive and significant relationship. Information and communication systems point out the procedures to be followed in fraud mitigation. Hayali et al., (2013) points out that an open and effective communication culture in organization aids in detecting the possibility of fraud in advance and thus puts necessary measures to prevent and mitigating fraud cases

Finally, the study concludes that monitoring activities have a positive and significant effect on fraud mitigation among Saccos in Kenya. Monitoring provides continuous surveillance of internal control and therefore it makes it easy to detect any risks as they arise and mitigate them.

\section{Recommendations}

The study established that all the elements of the internal control system have a positive and significant relationship with fraud mitigation. Thus it is recommended that Saccos should strive to implement internal control systems to a high extent in their organization, this will help reduce the cases of mitigation. Secondly, Strong measures should be put in place to check on employee's background, competency and integrity during recruitment. Strong regulation mechanisms should also be put in place to ensure employees only access relevant information as per their job or with appropriate approvals. Finally, appropriate models should be placed to detect, identify and deal with fraud in deposit-taking Saccos. There is a need for regular monitoring of third party links with deposit-taking Saccos'. This is vital for curtailing the boards and employees from indulging on collusions and other forms of fraudulent activities.

\section{Limitations and Suggestions for Future Studies}

There were a number of factors that limited the smooth execution of the analysis. To start with, the analysis was limited to primary information and not secondary information, since most of the information relating to fraud was not available, and the available information did not meet the analyzer's specifications. The study was constrained by time and finances and thus it was limited to deposit-taking Saccos based in Nairobi. This limitation will to some extent mean that the findings cannot be generalized to the entire Sacco sector in Kenya. Some subjects were also apprehensive about the confidentiality of the exercise due to the sensitivity of matters related to fraud in their institutions, which they felt would disadvantage them if revealed. This, therefore, posed a limitation to the analysis.

This study is focused on deposit-taking Saccos that are based in Nairobi only due to limitations of time and monetary constraints. Future studies may replicate it for all the Deposit-taking Saccos in Kenya.

Authors Contribution: David Riitho conceived the study, designed its contents, collected data and participated in the sequence alignment of the manuscript. Kevin Wanjala performed 
statistical analysis and drafted the manuscript. Both authors read and approved the final manuscript.

\section{Conflicts of Interest: The authors declare no conflict of interest.}

\section{REFERENCES}

Abbott, L.J., Parker, S. \& Park, Y. (2000). The Effects of Audit Committee Activity and Independence on Corporate Fraud. Managerial Finance 26 (11): 55-67.

Amudo, A. \& Inanga, E. L. (2009). Evaluation of Internal Control Systems: A case study from Uganda. International Analysis Journal of Finance and Economics, 17 (3), 145-158

Ayagre, P., Appiah-Gyamerah, I. \& Nartey, J. (2014). The effectiveness of internal control systems of banks: the case of Ghanaian banks. International Journal of Accounting and Finance Reporting, 4(2), 377-389.

Besley, T., \& Persson, T. (2013). Taxation and Development. Handbook of Public Economics, 5, 51-110.

Branch, B. \& Baker, C. (1998). Overcoming governance problem: what does it take? Paper presented at the Inter-America Development Bank (IDB) conference on credit unions, Washington DC: IDB

Cooper, D. R. \& Schindler, P. S. (2001). Business Analysis Methods. McGraw-Hill Higher Education, London.

COSO (1992). Components of internal control. Committee of Sponsoring Organization (COSO) of the trade way commission

COSO (2009). Enterprise Risk Management. Committee of Sponsoring Organization (COSO) of the trade way commission

Cressey, D.R. (1953). Other People's Money. Montclair, NJ: Patterson Smith

Elder, J. R., Zhang, Y., Zhou, J., \& Zhou N. (2008). Internal Control Weaknesses and Client Risk Management. Journal of Accounting, Auditing and Finance, 24 (4), 543-579.

Fayo G. (2019, March 4). Stima Investment Sacco board ousted in Sh500m land fraud probe. Business daily. Retrieved from: https://www.businessdailyafrica.com/news/Stima-Sacco-board-ousted-in-Sh500mland/539546-5008066-jyohh6/index.html

Fayo, G. (2018, November 14). Safaricom staff arrested in Sacco's fraud crackdown. Business Daily. Retrieved From. https://www.businessdailyafrica.com/corporate/companies/Safaricom-staff-arrested-in-saccos-fraudcrackdown/4003102-4852200-12ica8z/index.html

Fayo, G. (2019, March 11). Why Sh1trn Kenya Saccos are a ticking time bomb. Business Daily. Retrieved from: https://www.businessdailyafrica.com/news/Why-Sh1trn-Kenya-Saccos-time-bomb/539546-5018924uasitq/index.html

Grieves, J. (2000). Introduction: the Origins of Organisation Development. Journal of Management Development, 19 (5), 345-359

Hadi, N. A., \& Kamaluddin, A. (2015). Social Collateral, Repayment Rates, and the Creation of Capital Among the Clients of Microfinance. Procedia Economics and Finance, 31, 823-828.

Harvey, D. F. \& Brown, D. R. (1998). An experiential approach to Organisation Development. $3^{\text {rd }}$ Edition, Prentice-Hall, p.68

Hayali, A., Dinc, Y., Sarili, S., Secil, A. \& Aysel, G. (2013). Importance of internal control system in the banking sector: evidence from Turkey

Hayes R. (2005). Principles of Auditing, California; Pearson Education Limited

Holmes, S. A., Langford, M., Welch, O. J. \& Welch, S. T. (2002). Associations between internal controls and organizational citizenship behaviours. Journal of Managerial Issues, 14(1), 121-134

Idogei, S. O., Josiah, M. \& Onomuhara, O. G. (2017). Internal control as the basis for prevention, detection and eradication of frauds in banks in Nigeria. International Journal of Economics, Commerce and Management, 5(9), $57-71$

Institute of Internal Auditors (IIA) (1999). Definition of Internal Auditing. Altamonte Springs, FL:II: Canada 
Kamaliah, K., Noor-Syazana, M., Norhayati, M., Zuraidah, M. \& Rita, A. (2018). Effectiveness of monitoring mechanisms and mitigation of fraud incidents in the public sector. Administratie si Management Public, (30), 82-95

Kamau, E. N. (2016). An investigation of the causes and characteristics of fraud in Kenyan Saccos and whether Bedford's law can be used to detect fraud in accounting data. Unpublished master's thesis. Strathmore University

Kimani, J. (2011). Risk Assessment Plan for Barclays Bank of Kenya. Tampere University of Applied Sciences

Kiprop, C. N. (2010). Response strategies to fraud-related challenges by Barclays Bank of Kenya.Unpublished MBA Project Thesis university of Nairobi, Kenya.

Kothari, C. R. (2003). Analysis methodology, methods and techniques. Wisha Prakashan, New Delhi.

Kothari, C. R. (2004). Analysis methodology: methods and techniques. $2^{\text {nd }}$ Edition, New Age International Publishers

KPMG (2009). KPMG Fraud Survey 2009 Report. KPMG: Kuala Lumpur, Malaysia

Kulas, J. T., McInnerney, J. E., DeMuth R. F. \& Jadwinski, V. (2007). Employee satisfaction and theft: testing climate perceptions as a mediator. The Journal of Psychology, 141(4), 389-402

Le, T. T. H. \& Tran, M. D. (2018). The effect of internal control on asset misappropriation: The case of Vietnam. Business and Economic Horizons, 14 (4), 941-953.

Makau, S. M. (2017). An investigation of cash management practices of savings and credit cooperative societies in Nairobi County. Unpublished MBA project, USIU-A

Munyua, J.M. (2013). Operational response strategies to payment card fraud by commercial banks in Kenya. Unpublished MBA Project. The University of Nairobi.

Oguda, N. J., Odhiambo, A. \& Byaruhanga, J. (2015). Effect of internal control on fraud detection and prevention in district treasuries of Kakamega County. International Journal of Business and Management Invention, 4(1), 47-57

Okonkwo, I. V. \& Ezegbu, N. L. (2016). Internal control techniques and fraud mitigation in Nigerian banks. Journal of Economics and Finance, 7(5), 37-46

PROCASUR Africa (2012). An overview of Saccos in Kenya; in pursuit of ideas to develop Savings and Credit Cooperatives. Learning from Kenyan Saccos. March 2012, Kenya Report.

SASRA (2017). The SACCO supervision annual report, 2017.

Sekaran, U. (2006). Analysis methods for business: a skill-building approach. John Wiley \& Sons.

Serianu (2018). Sacco Cybersecurity Report, 2018. Demystifying cybersecurity for Saccos.

Tunji, S. (2013). The effective internal control system as an antidote for distress in the banking industry in Nigeria. Journal of Economics and International Business Analysis, 1(5), 106-121

Wanjama, P. (2019, February 19). New Police Unit to Bust Sacco Fraudsters. Kenya news.Retrieved from https://www.capitalfm.co.ke/business/2019/03/stima-sacco-distances-itself-from-troubled-stima-investmentsociety/

Wanyama, T. S. (2012). Effectiveness of fraud response strategies adopted by Cooperative Bank of Kenya Limited. Unpublished MBA Project of the University of Nairobi

Wilhelm, W. K. (2004). The fraud management lifecycle theory: A holistic approach to fraud management. Journal of Economic Crime Management, 2(2), 1-38

Wooldridge, J.M (2013). Introductory econometrics: A modern approach $5^{\text {th }}$ edition Mason, OH: South-Western

Zakaria, K. M., Nawawi, A. \& Salin, A. S. (2016). Internal controls and fraud - empirical evidence from oil and Gas Company. Journal of Financial Crime, 23(4), 1154-1168

Zhang, Y., Zhou, J., \& Zhou, N. (2007). Audit committee quality, auditor independence, and internal control weaknesses. Journal of Accounting and Public Policy, 26(3), 300-327. Attribution (CC BY) license (http://creativecommons.org/licenses/by/4.0/). 